\title{
ANALISIS IMPLEMENTASI KURIKULUM BERBASIS KEWIRAUSAHAAN DALAM MEMBENTUK SIKAP WIRAUSAHA PADA SISWA JENJANG PENDIDIKAN DASAR DI KABUPATEN KEBUMEN
}

\author{
ANALYSIS OF THE IMPLEMENTATION OF AN ENTREPRENEURED \\ CURRICULUM IN FORMING ATTITUDES OF ENTREPRENEURSHIP IN \\ BASIC EDUCATION STUDENTS IN KEBUMEN DISTRICT
}

\author{
Ervian Arif Muhafid ${ }^{1)}$, Rasyid Zuhdi ${ }^{2)}$ \\ ${ }^{1,2}$ Fisika, FMIPA, Universitas Ma'arif Nahdlatul Ulama Kebumen \\ ${ }^{1}$ Email: rvian.a.muhafid@umnu.ac.id
}

\begin{abstract}
ABSTRAK
Penelitian ini bertujuan untuk mengetahui implementasi kurikulum berbasis kewirausahaan dalam membentuk sikap wirausaha pada siswa jenjang pendidikan dasar di Kabupaten Kebumen serta mendeskripsikan desain kurikulum berbasis kewirausahaan untuk membentuk sikap wirausaha pada siswa jenjang pendidikan dasar di Kabupaten Kebumen. Metode Penelitian yang dilakukan adalah kualitatif dengan pendekatan yang digunakan adalah deskriptrif kualitatif yang diharapkan mampu mendeskripsikan secara utuh obyek yang diteliti. Hasil penelitian dan pembahasan menunjukan bahwa implementasu kurikulum berbasis kewirausahaan diperoleh data rata-rata aspek kewirausahaan sudah diterapkan di sekolah dengan skor wawancara 2,64 dengan kategori baik. Hal ini membuktikan bahwa kewirausahaan sudah diterapkan di jenjang Pendidikan dasar di Kabupaten Kebumen. Desain kurikulum berbasis kewirausahaan di Kabupaten Kebumen adalah (1) terintegrasi pada seluruh mata pelajaran; (2) terpadu dalam ekstrakurikuler; (3) melalui praktik berwirausaha disekolah; (4) terintegrasi pada bahan ajar; (5) pembiasaan dalam kultur sekolah; (6) terintegrasi pada muatan lokal.
\end{abstract}

Kata kunci: Kurikulum, Kewirausahaan, Sikap wirausaha, Pendidikan dasar.

\begin{abstract}
This research aims to determine the implementation of entrepreneurship-based curriculum in forming entrepreneurial attitudes in basic education students in Kebumen Regency and to describe entrepreneurship-based curriculum designs to form entrepreneurial attitudes in basic education students in Kebumen Regency. The research method used is qualitative with the approach used is descriptive qualitative which is expected to be able to fully describe the object under research. The results show that the entrepreneurship-based curriculum implementation shows that the average entrepreneurial aspect has been applied in schools with an interview score of 2.64 in a good category. This proves that entrepreneurship has been implemented at the basic education students in Kebumen Regency. The entrepreneurship-based curriculum design in Kebumen Regency is (1) integrated in all subjects; (2) integrated in extracurricular activities; (3) through entrepreneurial practices in schools; (4) integrated in teaching materials; (5) habituation in school culture; (6) integrated into local content.
\end{abstract}

Keywords: Curriculum, Entrepreneurship, Entrepreneurial attitude, Basic education. 
P-ISSN 2580 - 7781

E-ISSN $2615-3238$

\section{PENDAHULUAN}

Saat ini, dunia tengah memasuki era revolusi industri 4.0. atau revolusi industri dunia ke- empat dimana teknologi telah menjadi basis dalam kehidupan manusia. Segala hal menjadi tanpa batas dan tidak terbatas akibat perkembangan internet dan teknologi digital. Era ini telah mempengaruhi banyak aspek kehidupan baik di bidang ekonomi, politik, kebudayaan, seni, dan bahkan sampai ke dunia pendidikan. Masyarakat Ekonomi ASEAN (MEA) juga telah resmi dilaksanakan oleh seluruh Negara di ASEAN pada 1 Januari 2016. MEA adalah momentum pasar bebas antar warga ASEAN diberlakukan. Produk-produk luar negeri akan mudah didapat dengan harga yang murah, hal ini tentu membuat persaingan ekonomi semakin sengit. Selain itu, jumlah lapangan pekerjaan di Indonesia juga akan semakin sedikit karena kedatagan warga Negara asing yang akan melamar pekerjaan.

Masalah pengangguran merupakan tantangan besar bagi pemerintah dan masyarakat Indonesia. Selama beberapa tahun terakhir, angka pengangguran selalu mengalami kenaikan (Astri \& Latifah, 2016). Sampai saat ini, angka pengangguran oleh kelompok pendidikan tinggi termasuk dalam kategori tinggi. Hal tersebut dapat dilihat dari data yang didapat Badan Pusat Statistik (BPS) tahun 2017 menyatakan bahwa jumlah pengangguran terbuka berkisar sekitar 7 juta orang. Persentase pengangguran terbesar dari tingkat pendidikan adalah (1) SMA 27\%; (2) SMK 23\%; (3) SMP 18\%; (4) SD 13\%; (5) Perguruan Tinggi 12\% (BPS, 2017). Dimana dari jumlah tersebut dapat dilihat masih banyak pengangguran yang berasal dari SD dan SMP.

Salah satu masalah yang dihadapi dunia pendidikan di Indonesia adalah pentingnya hasil belajar dari pada proses pembelajaran (Muhafid, 2015). Pembelajaran tidak hanya soal hasil akan tetapi ada yang lebih penting yaitu proses pembelajaran. Pendidikan Kewirausahaan menjadi penting didalam proses pembelajaran. Pentingnya pendidikan kewirausahaan di sekolah, dapat ditempuh melalui beberapa jalur, baik jalur intrakurikuler maupun ekstrakurikuler. Dari jalur intrakurikuler berupa implementasi kurikulum yang ada melalui pembelajaran di kelas. Adapun jalur ekstrakurikuler dapat berupa pembentukan 
kelompok-kelompok kewirausahaan yang menampung siswa yang berminat. Hal ini sejalan dengan pendapat Sri Yuliati, seorang pakar pendidikan dari komunitas homeschooling Indonesia dalam Wijatno (2009) yang menjelaskan tentang paradigma pemenuhan hak anak agar menjadi anak merdeka dengan memberikan pedidikan yang bersifat life skill dan salah satunya adalah Pendidikan kewirausahaan atau entrepreneurship. Perlu adanya pengenalan kewirausahaan sejak dini yang bertujuan untuk membentuk karakter wirausaha anak-anak, yaitu kepemimpinan, optimis dan berani mengambil resiko maka dari itu, peneliti mengembangkan pendidikan kewirausahaan di Pendidikan dasar agar mereka mampu mengaplikasikannya di masa depan nanti.

Peneliti melakukan penelitian yang berjudul "analisis implementasi kurikulum berbasis kewirausahaan dalam membentuk sikap wirausaha pada siswa jenjang pendidikan dasar di Kabupaten Kebumen”. Penelitian ini bertujuan untuk mengetahui implementasi kurikulum berbasis kewirausahaan dalam membentuk sikap wirausaha pada siswa jenjang pendidikan dasar dan mendeskripsikan desain kurikulum berbasis kewirausahaan untuk membentuk sikap wirausaha pada siswa jenjang pendidikan dasar di Kabupaten Kebumen. Hasil penelitian ini diharapkan dapat menjadi rujukan dan bahan pertimbangan bagi pemangku kebijakan dalam mengembangkan kurikulum berbasis kewirausahaan pada jenjang pendidikan dasar.

\section{Pendidikan Kewirusahaan}

Menurut Muhammad Saroni (2012) pendidikan kewirausahaan adalah suatu program pendidikan yang menggarap aspek kewirausahaan sebagai bagian penting dalam pembekalan kompetensi siswa. Sedangkan menurut Kasmir (2006) pendidikan kewirausahaan harus mampu mengubah pola pikir siswa, melalui pendidikan kewirausahaan mampu mendorong peserta didik untuk berwirausaha mandiri. Sedangkan menurut Eman Suherman (2010), pendidikan kewirausahaan merupakan semacam pendidikan yang mengajarkan agar orang mampu menciptakan usaha sendiri. Lebih Lanjut Chung-Gyu Byun (2018) dalam penelitian menyimpulkan bahwa pengembangan berbagai mata pelajaran harus diprioritaskan untuk pengembangan pendidikan kewirausahaan serta para ahli dan 
pendidik di setiap bidang harus bekerja sama untuk meningkatkan kualitas program kurikulum yang direncanakan.

\section{Nilai-nilai Pokok dan Integrasi Pendidikan Kewirausahaan pada Jenjang Pendidikan Dasar}

Nilai-nilai yang dikembangkan dalam pendidikan kewirausahaan adalah pengembangan nilai-nilai dan ciri-ciri seorang wirausaha. Menurut para ahli kewirausahaan, ada banyak nilai-nilai kewirausahaan yang mestinya dimiliki oleh siswa maupun warga sekolah yang lain. Berikut merupakan nilai-nilai kewirausahaan besera deskripsinya yang akan diintegrasikan melalui pendidikan kewirausahaan (Harianti, 2010). Fitriati (2011) Melakukan penelitian di beberapa universitas menyimpulkan bahwa pendidikan kewirausahaan yang diterapkan di setiap universitas memiliki nilai tambah yang unik dan lokal kebijaksanaan sesuai dengan visi, misi, dan tujuan masing-masing universitas. Hal tersebut bisa dijalankan di tingkat pendidikan dasar dengan harapan menjadi bekal jiwa wirausaha siswa serta menjadi nilai tambah yang unik bagi sekolah tersebut.

Berikut ini nilai-nilai dan deskripsi nilai pendidikan kewirausahaan yang dapat diterapkan di jenjang pendidikan dasar 
Tabel 1. Nilai-Nilai dan Deskripsi Nilai Pendidikan Kewirausahaan

\begin{tabular}{|c|c|}
\hline Nila-nilai & Deskripsi \\
\hline 1. Mandiri & $\begin{array}{l}\text { Sikap dan perilaku yang tidak mudah tergantung } \\
\text { pada orang lain dalam menyelesaikan tugas-tugas. }\end{array}$ \\
\hline 2. Kreatif & $\begin{array}{l}\text { Berpkir dan melakukan sesuatu untuk menghasilkan } \\
\text { cara atau hasil berbeda dari produk atau jasa yang } \\
\text { telah ada. }\end{array}$ \\
\hline $\begin{array}{l}\text { 3. Berani } \\
\text { mengambil resiko }\end{array}$ & $\begin{array}{l}\text { Kemampuan seseorang untuk mentukai pekerjaan } \\
\text { yang menantang, berani dan mampu mengambil } \\
\text { resiko kerja }\end{array}$ \\
\hline $\begin{array}{l}\text { 4. Berorientsi pada } \\
\text { tindakan }\end{array}$ & $\begin{array}{l}\text { Mengambil inisiatif untuk bertindak dan buka } \\
\text { mengganggu, sebelum sebuah kejadian yang tidak } \\
\text { dikehendaki terjadi }\end{array}$ \\
\hline 5. Kepemimpinan & $\begin{array}{l}\text { Sikap dan perilaku seseorang yag selalu terbuka } \\
\text { terhadap saran dan kritik, mudh bergaul, bekerjasama } \\
\text { dan mengarahkan orang lain. }\end{array}$ \\
\hline 6. Kerja keras & $\begin{array}{l}\text { Perilaku yang menunjukkan upaya sungguh-sungguh } \\
\text { dalam menyelesaikan tugas dan mengatasi berbagai } \\
\text { hambatan. }\end{array}$ \\
\hline 7. Jujur & $\begin{array}{l}\text { Perilaku yang didasarkan pada upaya yang } \\
\text { menjadikan dirinya sebagai orang yang selalu dapat } \\
\text { dipercaya dalam perkataan, tindakan dan pekerjaan. }\end{array}$ \\
\hline 8. Disiplin & $\begin{array}{l}\text { Tindakan yang menunjukkan perilaku tertib dan } \\
\text { patuh pada berbagai ketentuan dan peraturan. }\end{array}$ \\
\hline 9. Inovatif & $\begin{array}{l}\text { Kemampuan untuk menerakan kreativitas dalam } \\
\text { rangka memecahkan persoalan-persoalan dan } \\
\text { peluang untuk meningkatkan dan memperkaya } \\
\text { kebidupan. }\end{array}$ \\
\hline
\end{tabular}

(Sumber: Kemendiknas Balitbang Puskurbuuk, 2010)

Pengintegrasian pendidikan kewirausahaan di dalam setiap satuan pendidikan di dasarkan pada framework yang disajikan dalam ilustrasi berikut. 


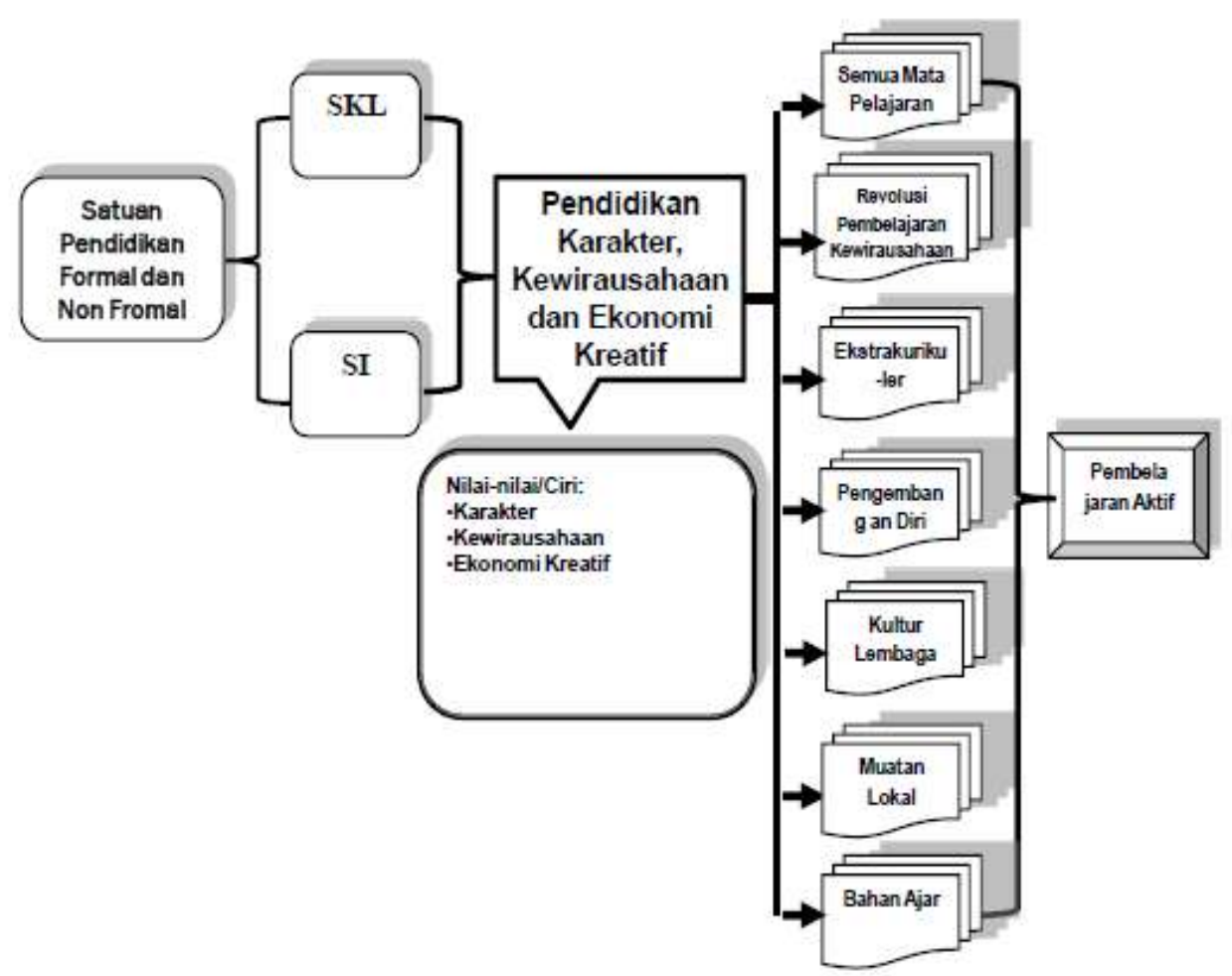

Gambar 1. Framework Pengintegrasian Pendidikan Kewirausahaan di Setiap Satuan

Sumber: Kemendiknas Balitbang Puskurbuuk, 2010

\section{METODE PENELITIAN}

Jenis penelitian yang digunakan pada penelitian ini adalah deskriptif. Pendekatan yang digunakan dalam penelitian ini adalah deskriptrif kualitatif yang diharapkan mampu mendeskripsikan secara utuh obyek yang diteliti. Penelitian dilaksanakan pada bulan Juli sampai dengan bulan Oktober 2020. Teknik pengambilan sampel pada penelitian adalah teknik purposive sampling, yaitu teknik pengambilan sampel dengan pertimbangan tertentu. Pertimbangan yang diambil yaitu sekolah-sekolah yang memiliki nilai rata-rata Ujian Nasional (UN) tertinggi di setiap Rayon di Kabupaten Kebumen. Dengan mempertimbangkan hal di atas dan membatasi penelitian, maka unit analisis dalam penelitian ini ditentukan dengan sengaja (purposive) yaitu 1 Sekolah SD dan SMP setiap rayon yang memiliki nilai rata- rata UN tertinggi.

Cara dan instrumen pengumpulan data dilakukan dengan tiga macam metode yang digunakan dalam mengumpulkan data yaiu dengan wawancara yang 
dilakukan dengan Kepala Sekolah, Waka Kurikulum, guru mata pelajaran serta siswa. Wawancara yang dilakukan menggunakan skala rangking, sehingga jawaban dari pertanyaan dapat dirubah dalam bentuk skor yang selanjutnya data yang berupa skor diubah menjadi data kualitatif (data interval) dengan skala empat (Khabibah, 2006). Observasi dilakukan oleh peneliti dengan cara melihat langsung ke sekolah. Tujuan observasi ini adalah untruk memperoleh gambaran yang jelas tentang objek penelitian baik secara fisik, geografis, sosial, sertra sarana prasarana. Dokumentasi pada penelitian ini dilakukan untuk memperoleh data Profil sekolah serta dokumentasi kegiatan Observasi serta wawancara

Teknik analisis data dilakukan dengan tahapan validasi instrumen dan data hasil wawancara. Adapun penjelasan teknis analisis data untuk setiap tahapan tersebut adalah validasi Instrumen yang dilakukan dengan menyiapkan instrument wawancara kemudian diberikan pada ahli/pakar. Data yang berupa skor diubah menjadi data kualitatif (data interval) dengan skala empat (Khabibah, 2006). Adapun model analisis data yang akan peneliti gunakan dalam penelitian ini yaitu analisis data interaktif model Miles dan Huberman. Menurut Miles dan Huberman analisis data ini meliputi kegiatan pengumpulan data, reduksi data, penyajian data dan verifikasi data. Pada penelitian ini peneliti melakukan pengumpulan data mentah terlebih dahulu sebelum melakukan reduksi data untuk menyederhanakan data yang telah dikumpulkan sehingga perlu dianalisis data melalui reduksi data agar fokus pada penelitian untuk selanjutnya di simpulkan dan diverifikasi. peneliti memastikan apakah interpretasi dan temuan penelitian akurat. Maka dalam hal ini peneliti menggunakan teknik triangulasi. Triangulasi yang digunakan dalam penelitian ini adalah triangulasi sumber adalah menggali kebenaran informasi tertentu melalui berbagai metode dan sumber perolehan data, dalam hal ini peneliti membandingkan hasil wawancara yang diperoleh dari siswa, guru, waka kurikulum dan kepala sekolah terkait dengan implementasi pendidikan kewirausahaan dalam membentuk sikap wirausaha pada siswa. 


\section{HASIL PENELITIAN DAN PEMBAHASAN}

Penelitian ini dilaksanakan dengan tujuan untuk mengetahui implementasi kurikulum berbasis kewirausahaan dalam membentuk sikap wirausaha pada siswa jenjang pendidikan dasar di Kabupaten Kebumen dan mendeskripsikan desain kurikulum berbasis kewirausahaan untuk membentuk sikap wirausaha pada siswa jenjang pendidikan dasar di Kabupaten Kebumen. Penelitian yang dilakukan adalah kualitatif dengan pendekatan yang digunakan adalah deskriptrif kualitatif yang diharapkan mampu mendeskripsikan secara utuh obyek yang diteliti. Pengambilan data dilakukan melalui wawancara. Wawancara dilakukan menggunakan instrumen wawancara yang telah disusun dan divalidasi sehingga instrument wawancara yang digunakan dinyatakan layak untuk mengambil data.

Berdasarakan hasil validasi instrument wawancara yang dilakukan oleh Pakar. Pakar tersebut adalah Ahli Bahasa Universitas Ma'arif Nahdlatul Ulama Kebumen. Berdasarakan Hasil Validasi didapatkan skor 3,4 dengan kategori baik. Dari 50 pertanyaan direduksi menjadi 39 pertanyaan yang dinyatakan layak untuk digunakan. Selanjutnya instrumen yang sudah layak kemudian di gunakan untuk mengambil data dilapangan melalui wawancar secara langsung dan secara tidak langsung (online). Berikut ini data hasil validasi instrumen disajikan pada tabel 2.

Tabel 2. Hasil Validasi Instrumen

\begin{tabular}{llccc}
\hline No & \multicolumn{1}{c}{ Aspek } & Skor & $\begin{array}{c}\text { Skor } \\
\text { Rata-Rata }\end{array}$ & Kategori \\
\hline 1 & Kejelasan & 3,5 & & \\
2 & Ketepatan & 3 & & Baik \\
3 & Relevansi & 3,5 & 3,4 & \\
4 & Kevalidan & 3 & & \\
5 & Ketepatan bahasa & 3,7 & & \\
\hline
\end{tabular}

Instrumen yang telah divalidasi dan dinyatakan valid kemudian dapat digunakan untuk mengambil data dilapangan. Berdasarkan hasil wawancara implementasi kewirausahaan yang dilaksanakan di sekolah kepada Kepala Sekolah, Waka Kurikulum, Guru dan Siswa diperoleh data sesuai pada tabel 3 dibawah ini: 
Tabel 3. Skor hasil wawancara implementasi nilai-nilai kewirausahaan di sekolah

\begin{tabular}{clc}
\hline No & \multicolumn{1}{c}{ Sekolah } & Skor \\
\hline 1 & SD N 1 Prembun & 2,4 \\
2 & SMP N 1 Prembun & 2,6 \\
3 & SD N 1 Petanahan & 2,1 \\
4 & SMP N 1 Ayah & 2,4 \\
5 & SD N 1 Ayah & 2,4 \\
6 & SMP N 1 Ayah & 3,2 \\
7 & SD N 1 Karangsambung & 2,2 \\
8 & SMP N 1 Karangsambung & 2,2 \\
9 & SD N 1 Kutosari & 3,3 \\
10 & SMP N 1 Kebumen & 3,6 \\
& $\quad$ Rata-rata & 2,64 \\
\hline
\end{tabular}

Berdasarkan tabel tersebut wawancara yang dilakukan dengan Kepala Sekolah, Waka Kurikulum, Guru dan Siswa yang dilakukan pada sekolah sampel di Kabupaten Kebumen diperoleh data rata-rata aspek kewirausahaan sudah diterapkan di sekolah dengan skor wawancara 2,64 dengan kategori baik. Skor terendah di peroleh pada Jenjang SD adalah SD N 1 Karangsambung dan Jenjang SMP adalah SMP N 1 Karangsambung. Hal itu dikarenakan di sekolah tersebut siswa nya dikategorikan siswa-siswa yang berasal dari pedesaan yang belum sadar pentingnya Pendidikan. Siswa-siswa di sekolah daerah tersebut belum begitu semangat dalam belajar hanya berdasar rutinitas untuk selalu sekolah setiap pagi. Skor tertinggi jenjang SD diperoleh oleh SD N 1 Kutosari dan jenjang SMP diperoleh oleh SMP N 1 Kebumen. Hal tersebut dikarenakan sekolah tersebut berada diperkotaan yang sudah sadar Pendidikan dan persaingan pembelajaran yang ketat serta dukungan sarana prasarana dan dukungan berbagai pihak terkait. Wawancara dengan berbagai unsur dilaksanakan untuk menggali informasi secara mendalam terkait dengan implementasi kurikulum di sekolah. Secara keseluruhan disajikan pada informasi berikut ini.

Hasil wawancara disetiap sekolah di buat rata-rata untuk mendapatkan hasil wawancara dengan kepala sekolah, waka kurikulum, guru, dan siswa dari setiap sekolah. Hal itu dilakukan untuk mengetahui kecenderungan aspek kewirausahaan yang diperoleh berdasarkan pendapat dari semua warga sekolah. Dibawah ini Rekap hasil wawancara Kepala Sekolah ditampilan dalam Tabel 4. 
Tabel 4. Rerata Skor Hasil Wawancara Kepala Sekolah

\begin{tabular}{clc}
\hline No & \multicolumn{1}{c}{ Aspek } & Skor \\
\hline 1 & Pendidikan kewirausahaan terintegrasi dalam seluruh mata pelajaran & 3,1 \\
2 & $\begin{array}{l}\text { Pendidikan kewirausahaan yang terpadu dalam kegiatan } \\
\text { Ekstrakurikuler }\end{array}$ & 2,1 \\
3 & $\begin{array}{l}\text { Pendidikan kewirausahaan melalui pengembangan diri } \\
4\end{array}$ & $\begin{array}{l}\text { Perubahan pelaksanaan pembelajaran kewirausahaan dari } \\
\text { konsep/ teori ke dalam pembelajaran praktik berwirausaha }\end{array}$ \\
5 & $\begin{array}{l}\text { Pengintegrasian pendidikan kewirausahaan ke dalam bahan ajar/ } \\
\text { Buku ajar }\end{array}$ & 2,1 \\
6 & $\begin{array}{l}\text { Pengintegrasian pendidikan kewirausahaan melalui kultur sekolah } \\
7\end{array}$ & $\begin{array}{l}\text { Pengintegrasian pendidikan kewirausahaan melalui muatan local } \\
\text { Rata-rata }\end{array}$ \\
\hline
\end{tabular}

Berdasarkan wawancara dengan kepala sekolah rata-rata aspek kewirausahaan yang diperoleh adalah 2,9 dengan kategori baik. Aspek Pendidikan kewirausahaan yang terpadu dalam kegiatan Ekstrakurikuler masih rendah. Hal itu dikarenakan Pendidikan kewirausahaan belum di munculkan dalam kegiatan ekstrakurikuler yang diadakan di sekolah. Ekstrakurikuler yang diadakan sekolah masih terfokus dalam pengembangan diri siswa belum mengenalkan jiwa wirausaha. Selain itu aspek Pengintegrasian pendidikan kewirausahaan ke dalam bahan ajar/ Buku ajar juga masih rendah. Hal tersebut dikarenakan aspek kewirausahaan belum di integrasikan dalam bahan ajar/buku ajar mata pelajaran sehari-hari. Sebagian besar bahan ajar yang ada tidak dikembangkan oleh Guru akan tetapi diperoleh dari Pemerintah atau percetakan sehingga didalamnya belum terintegrasi aspek kewirausahaan. Seorang kepala sekolah, pengawas, atau kepala dinas pendidikan kabupaten/kota, harus memiliki ilmu pengetahuan yang luas di bidang pekerjaan yang menjadi kewenangan dan tanggung jawabnya (Suwithi, 2019).

Kepala sekolah sebagai kunci keberhasilan program kewirausahaan di sekolah harus memiliki pola pikir didalam jiwa kepemimpinanya jiwa wirausaha karena pada dasarnya seorang Kepala Sekolah harus berjiwa enterpreneur. Wirausaha dapat diciptakan melalui upaya-upaya sistem pendidikan yang dapat menstimulasi pola pikir (mindset) orang agar berminat menjadi wirausahawan (Shane et al., (2003), Alberti et al., (2004), Hendro (2011), dan Otuya et al (2013). 
Wawancara dengan wakil kepala sekolah bidang kurikulum dilaksanakan hanya pada jenjang SMP. Pada jenjang SD tidak ada wakil kepala sekolah bidang kurikulum sehingga tidak dilakukan wawancara. Hasil wawancara dengan wakil kepala sekolah disajikan dalam tabel 5 dibawah ini:

Tabel 5. Rerata Skor Hasil Wawancara Wakil Kepala Sekolah Bidang Kurikulum

\begin{tabular}{clc}
\hline No & \multicolumn{1}{c}{ Aspek } & Skor \\
\hline 1 & $\begin{array}{l}\text { Pendidikan kewirausahaan terintegrasi dalam seluruh mata } \\
\text { pelajaran }\end{array}$ & 3,1 \\
2 & $\begin{array}{l}\text { Pendidikan kewirausahaan yang terpadu dalam kegiatan } \\
\text { Ekstrakurikuler }\end{array}$ & 2,6 \\
3 & $\begin{array}{l}\text { Pendidikan kewirausahaan melalui pengembangan diri } \\
4\end{array}$ & $\begin{array}{l}\text { Perubahan pelaksanaan pembelajaran kewirausahaan dari } \\
\text { konsep/ teori ke dalam pembelajaran praktik berwirausaha }\end{array}$ \\
5 & $\begin{array}{l}\text { Pengintegrasian pendidikan kewirausahaan ke dalam bahan ajar/ } \\
\text { Buku ajar }\end{array}$ & 2,1 \\
6 & $\begin{array}{l}\text { Pengintegrasian pendidikan kewirausahaan melalui kultur sekolah } \\
7\end{array}$ & $\begin{array}{l}\text { Pengintegrasian pendidikan kewirausahaan melalui muatan local } \\
\text { Rata-rata }\end{array}$ \\
\hline
\end{tabular}

Berdasarkan hasil wawancara dengan wakil kepala sekolah bidang kurikulum diperoleh rata-rata aspek kewirausahaan 2,86 dengan kategori baik. Wahyuni (2017) menyatakan bahwa Hasil yang diperoleh dari pembentukan wirausaha peserta didik dari kegiatan-kegiatan yang telah dilaksanakan dengan dijembatani oleh kurikulum tematik terpadu terlihat dari munculnya sikap mandiri, tawakkal kreatif dan inovatif, percaya diri, disiplin, mempunyai rasa tangung jawab dan berani mengambil resiko, terbentuk sikap kepemimpinan dan bertoleransi terhadap guru, teman sebaya, dan orang lain. Berdasarkan pendapat tersebut mengamanatkan bahwa Kurikulum menjadi unsur penting dalam mensukseskan integrasi wirausaha dalam pembelajaran di sekolah.

Aspek Pendidikan kewirausahaan yang terpadu dalam kegiatan Ekstrakurikuler masih rendah. Hal itu dikarenakan Pendidikan kewirausahaan belum di munculkan dalam kegiatan ekstrakurikuler yang diadakan di sekolah. Ekstrakurikuler belum termasuk dalam kurikulum yang disusun. Nisa (2018) menerangkan bahwa untuk meraliasasikan visi dan misi sekolah untuk mengadakan ekstrakurikuler kewirausahaan dengan tujuan untuk membentuk 
karakter siswa-siswi memiliki jiwa entrepreneur. Kurikulum belum mengamanatkan secara tersirat Pendidikan kewirausahaan didalam kurikulum. Selain itu aspek Pengintegrasian pendidikan kewirausahaan ke dalam bahan ajar/ Buku ajar juga masih rendah. Hal tersebut dikarenakan aspek kewirausahaan belum di integrasikan dalam bahan ajar/buku ajar mata pelajaran sehari-hari. Sebagian besar bahan ajar yang ada tidak dikembangkan oleh Guru akan tetapi diperoleh dari Pemerintah atau percetakan sehingga didalamnya belum terintegrasi aspek kewirausahaan. Bagian kurikulum mengikuti regulasi yang ada belum mengharuskan untuk mengintegrasikan aspek kewirausahaan dalam pembelajaran. Pelaksanaan pendidikan kewirausahaan tidak harus mandiri atau otonom dengan membuat kurikulum baru. Tetapi,pendidikan kewirausahaan dapat diintegrasikan dalam kurikulum yang sudah ada, praktisnya dalam pembelajaran pada setiap mata pelajaran (Wibowo, 2011)

Wawancara dilakukan dengan guru sebagai subyek yang bersinggungan langsung dengan siswa. Hasil wawancara dengan guru sekabupaten kebumen disajikan dalam tabel 6.

Tabel 6. Rerata Skor Hasil Wawancara Guru Mata Pelajaran

\begin{tabular}{clc}
\hline No & \multicolumn{1}{c}{ Aspek } & Skor \\
\hline 1 & Pendidikan kewirausahaan terintegrasi dalam seluruh mata pelajaran & 3 \\
2 & $\begin{array}{l}\text { Pendidikan kewirausahaan yang terpadu dalam kegiatan } \\
\text { Ekstrakurikuler }\end{array}$ & 2 \\
3 & $\begin{array}{l}\text { Pendidikan kewirausahaan melalui pengembangan diri } \\
4\end{array}$ & 2,9 \\
& $\begin{array}{l}\text { Perubahan pelaksanaan pembelajaran kewirausahaan dari } \\
\text { konsep/ teori ke dalam pembelajaran praktik berwirausaha }\end{array}$ & 2,9 \\
5 & Pengintegrasian pendidikan kewirausahaan ke dalam bahan ajar/ & 2,4 \\
& Buku ajar & 3,2 \\
6 & Pengintegrasian pendidikan kewirausahaan melalui kultur sekolah & 2,9 \\
7 & Pengintegrasian pendidikan kewirausahaan melalui muatan local & 2,76 \\
\hline
\end{tabular}

Berdasarkan wawancara dengan guru rata-rata aspek kewirausahaan yang diperoleh adalah 2,76 dengan kategori baik. Aspek Pendidikan kewirausahaan yang terpadu dalam kegiatan Ekstrakurikuler masih rendah. Hal itu dikarenakan guru belum memunculkan pendidikan kewirausahaan belum di munculkan dalam kegiatan ekstrakurikuler yang diadakan di sekolah. Ekstrakurikuler yang diadakan 
sekolah masih terfokus dalam pengembangan diri siswa belum mengenalkan jiwa wirausaha. Selain itu aspek Pengintegrasian pendidikan kewirausahaan ke dalam bahan ajar/Buku ajar juga masih rendah. Hal tersebut dikarenakan aspek kewirausahaan belum di integrasikan dalam bahan ajar/buku ajar mata pelajaran sehari-hari. Sebagian besar bahan ajar yang ada tidak dikembangkan oleh Guru akan tetapi diperoleh dari Pemerintah atau percetakan sehingga didalamnya belum terintegrasi aspek kewirausahaan. Selain itu pada tahapan perencanaan guru mengalami kesulitan untuk memasukkan nilai-nilai kewirausahaan ke dalam mata pelajaran.

Siswa juga dilakukan wawancara untuk mengetahui aspek kewirausahaan yang sudah berkembang di sekolah. Wawancara dilakukan kepada 3 siswa yaitu siswa jenjang SD kelas 4, 5, 6 dan jenjang SMP kelas 7, 8, 9. Hasil wawancara dengan siswa ditunjukan pada tabel 7.

Tabel 7. Rerata Skor Hasil Wawancara Siswa

\begin{tabular}{clc}
\hline No & \multicolumn{1}{c}{ Aspek } & Skor \\
\hline 1 & Pendidikan kewirausahaan terintegrasi dalam seluruh mata pelajaran & 3,1 \\
2 & $\begin{array}{l}\text { Pendidikan kewirausahaan yang terpadu dalam kegiatan } \\
\text { Ekstrakurikuler }\end{array}$ & 2 \\
3 & $\begin{array}{l}\text { Pendidikan kewirausahaan melalui pengembangan diri } \\
4\end{array}$ & 3,2 \\
& $\begin{array}{l}\text { Perubahan pelaksanaan pembelajaran kewirausahaan dari } \\
\text { konsep/ teori ke dalam pembelajaran praktik berwirausaha }\end{array}$ & 3,1 \\
5 & $\begin{array}{l}\text { Pengintegrasian pendidikan kewirausahaan ke dalam bahan ajar/ } \\
\end{array}$ & 2,4 \\
6 & $\begin{array}{l}\text { Puku ajar } \\
7\end{array}$ & $\begin{array}{l}\text { Pengintegrasian pendidikan kewirausahaan melalui kultur sekolah } \\
\text { Rata-rata }\end{array}$ \\
\hline
\end{tabular}

Berdasarkan wawancara dengan siswa rata-rata aspek kewirausahaan yang diperoleh adalah 2,87 dengan kategori baik. Agustina (2017) menyimpulkan bahwa Pendidikan kewirausahaan merupakan komponen penting dalam meningkatkan kompetensi dan kemandirian siswa untuk menangkap peluang di era pasar bebas. Berdasarkan pendapat tersebut bahwa Pendidikan kewirausahaan sangatlah penting untuk menyiapkan siswa dalam kehidupan dewasa kelak. Lebih lanjut Agustina (2017) menyatakan bahwa pendidikan yang berwawasan kewirausahan menjadi lebih bermanfaat dan akan memberikan peluang tumbuh 
dan berkembangnya kearah potensi kreativitas dan inovasi anak yang pada akhirnya pribadi yang memiliki karakter kreatif, inovatif, bertanggung jawab, disiplin dan konsisten akan memilki kemampuan kewirausahaan. Pendapat Sandiaga Uno dalam Wardhana (2013) menyatakan bahwa kewirausahaan bertujuan untuk menjadikan seseorang menjadi lebih baik, bukan semata- mata membuat seseorang menjadi kaya. Kewirausahaan adalah tentang kerjasama dengan orang lain, karena kewirausahaan juga berbicara tentang bagaimana memberikan manfaat bagi orang lain. Melalu ipendidikan kewirausahaan ini diharapkan kelak anak dapat mandiri dan memberikan kesempatan bekerja bagi orang lain.

Aspek Pendidikan kewirausahaan yang terpadu dalam kegiatan Ekstrakurikuler masih rendah. Hal itu dikarenakan Pendidikan kewirausahaan belum di rasakan oleh siswa dalam kegiatan ekstrakurikuler yang diadakan di sekolah. Ekstrakurikuler yang diadakan sekolah masih terfokus dalam pengembangan diri siswa belum mengenalkan jiwa wirausaha. Siswa belum dilatih beruasaha dalam kegiatan ekstrakurikuler. Siswa hanya membeli alat tulis dan buku di koperasi. Selain itu aspek Pengintegrasian pendidikan kewirausahaan ke dalam bahan ajar/ Buku ajar juga masih rendah. Hal tersebut dikarenakan aspek kewirausahaan belum di integrasikan dalam bahan ajar/buku ajar mata pelajaran sehari-hari. Siswa belum menerima dan menemukan aspek kewirausahaan didalam buku yang diberikan oleh sekolah. Sebagian besar bahan ajar yang ada tidak dikembangkan oleh Guru akan tetapi diperoleh dari Pemerintah atau percetakan sehingga didalamnya belum terintegrasi aspek kewirausahaan.

Pendidikan kewirausahaan menjadi suatu alternatif dan keharusan untuk jenjang pendidikan. Pendidikan dasar menjadi awal dalam pengenalan kewirausahaan dan sebagai bekal untuk kewirausahaan dijenjang berikutnya. Berikut acuan kewirausahaan yang dapat digunakan dalam pengembangan pendidikan kewirausahaan di sekolah jenjang pendidikan dasar:

1. Proses pengembangan aspek kewirausahaan merupakan sebuah proses panjang dan berkelanjutan dimulai dari awal peserta didik masuk sampai selesai dari suatu satuan pendidikan yang diawali di jenjang pendidikan dasar. 
2. Materi nilai-nilai kewirausahaan bukanlah bahan ajar biasa. Artinya, nilainilai tersebut tidak dijadikan pokok bahasan yang dikemukakan seperti halnya ketika mengajarkan suatu konsep, teori, prosedur, atau pun fakta seperti dalam mata pelajaran agama, bahasa Indonesia, PKn, IPA, IPS, dan sebagainya. Nilai kewirausahaan diintegrasikan ke dalam setiap mata pelajaran. Pengintegrasian ke dalam mata pelajaran bisa melalui materi, metode, maupun penilaian.

3. Dalam pelaksanaan pembelajaran di kelas, guru tidak perlu mengubah pokok.

4. Bahasan yang sudah ada tetapi menggunakan materi pokok bahasan itu untuk mengembangkan nilai-nilai kewirausahaan. Demikian juga, guru tidak harus mengembangkan proses belajar khusus untuk mengembangkan nilai.

5. Digunakan metode pembelajaran aktif dan menyenangkan.

Penerapan aspek kewirausahaan didalam pembelajaran tidak dilaksanakan sekaligus, namun dilakukan secara bertahap. Pembiasaan yang dilaksanakan secara terus menerus akan tertanam di jiwa. Penerapannya juga diimplementasikan konsep dan ketrampilan/skill kewirausahaan. Konsep dan keterampilan/skill kewirausahaan yang akan diimplementasikan setiap jenjang pendidikan berbeda kedalaman dan keluasannya. Jenjang SD/MI aspek kewirausahaanya akan lebih sedikit dari pada jenjang SMP/MTs. Penanaman nilai-nilai pendidikan kewirausahaan dapat juga ditanamkan melalui pembudayaan dalam seluruh aktifitas dan suasa sekolah. Pembudayaan akan menimbulkan suatu pembiasaan. Untuk menumbuhkan nilai-nilai pendidikan kewirausahaan sekolah perlu merencanakan suatu budaya dan kegiatan pembiasaan. Bagi peserta didik yang masih kecil, pembiasaan sangat penting. Karena dengan pembiasaan itulah akhirnya suatu aktivitas akan menjadi milik peserta didik di kemudian hari. Pembiasaan yang baik akan membentuk sosok manusia yang berkepribadian yang baik pula.

Hasil dari pelaksanaan pendidikan kewirausahaan di jenjang pendidikan dasar di Kabupaten Kebumen pada siswa belum bisa diukur secara pasti. Hal ini dikarenakan untuk mengukur karakter seseorang sudah tertanam atau belum membutuhkan waktu yang lama. Namun dengan pemberian pembiasaan aspek 
kewirausahaan dan pengetahuan tentang kewirausahaan, siswa dirasa lebih mandiri, kreatif, percaya diri, dan bertanggung jawab dalam aktivitas pembelajaran. Rachmadyanti (2016) menyebutkan pakar kepribadian dan Presiden Direktur Lembaga Pendidikan Duta Bangsa Mien Rachman Uno dalam Wijatno (2009) menyebutkan bahwa untuk menjadi wirausahawan handal, dibutuhkan karakter seperti kemampuan untuk dapat berkomunikasi,mampu membawa diri di berbagai lingkungan, menghargai waktu (time orientation), empati, mau berbagi dengan orang lain, mampu mengatasi stress, dapat mengendalikan emosi, dan mampu membuat keputusan. Mendidik anak menjadi seorang wirausahawan tidak dalam hitungan satu, dua, dan tiga bulan saja, melainkan harus menjadi sebuah proses yang panjang dan sistematis. Berdasarkan berbagai faktor yang mempengaruhi minat anak berwirausaha tersebut, maka sekolah sebagai lembaga formal wajib membimbing siswa, mengarahkan, dan menanamkan pendidikan kewirausahaan sejak dini. Melalui pembelajaran sehari-hari, guru dapat memahami karakter anak, minat anak, dan potensi anak. Jika mereka memiliki keinginan untuk berwirausaha kelak, maka sebagai guru harus memotivasi citacita mereka tesebut. Tidak bisa dipungkiri, mungkin tidak semua siswa senang berwirausaha, namun paling tidak sekolah memberikan fasilitas dan bimbingan guna menyalurkan nilai-nilai kebaikan dari memiliki jiwa entreprenurship. Karakter-karakter wirausaha yang dapat ditanamkan kepada siswa sekolah dasar dapat dimulai dari karakter-karakter baik, seperti, kreatif, mandiri, leadership, mampu memecahkan masalah, tidak mudah putus asa, mampu mengelola uang, dan dapat berinteraksi dengan orang lain. Berpikir dan bertindak kreatif adalah suatu upaya untuk menggunakan otak kanan secara aktif.

\section{KESIMPULAN}

Berdasarkan hasil penelitian dan pembahasan dapat disimpulkan bahwa Implementasi kurikulum berbasis kewirausahaan dalam membentuk sikap wirausaha pada siswa jenjang pendidikan dasar di Kabupaten Kebumen berada pada kategori baik dengan skor 2,64. Desain kurikulum berbasis kewirausahaan dikabupaten kebumen adalah (1) terintegrasi pada seluruh mata pelajaran; (2) terpadu dalam ekstrakurikuler; (3) melalui praktik berwirausaha disekolah; (4) 
P-ISSN 2580 - 7781

E-ISSN $2615-3238$

terintegrasi pada bahan ajar; (5) pembiasaan dalam kultur sekolah; (6) terintegrasi pada muatan lokal.

\section{DAFTAR PUSTAKA}

Agustina, Dwi Ampuni. 2017. Model Pembelajaran untuk Mengenalkan Kewirausahaan pada Siswa Sekolah Dasar Kelas Rendah. Jurnal Polines Bangun Rekaprima Vol.03 No 2.

Alberti, F; S. Sciascia dan A. Poli. 2004. Entrepreneurship Education: Notes on an Ongoing Debate. Disampaikan pada Proceedings of the 14th Annual International Entrepreneurship Conference, University of Nopoli, Federico II, Italy.

Astri, W., \& Latifah, L. 2016. Pengaruh Personal Attributes, Adversity Quotient dengan Mediasi Self Efficacy Terhadap Minat berwirausaha. Journal.unnes.ac.id, 5(2), 519-531.

Badan Pusat Statistik. 2017. Badan Pusat Statistik Tabel Dinamis. Diambil dari Badan Pusat Statistik:https://www.bps.go.id/site/resultTab, diakses 27 April 2019.

Balitbang Puskur. 2010. Pengembangan Pendidikan Budaya dan Karakter Bangsa: Pedoman Sekolah. Jakarta: Kemdiknas Balitbang Puskur.

Byun Chung-Gyu 1 et.al. 2018. A Study on the Effectiveness of Entrepreneurship Education Programs in Higher Education Institutions: A Case Study of Korean Graduate Programs. Journal of Open Innovation: Technology, Market, and Complexity, 4 (26).

Fitriati R, dkk. 2011. Entrepreneurship Education The Models Applied in Certain Universities. International Journal of Administrative Science \& Organization, 18 (3) ISSN 0854 - 3844.

Harianti, D. 2010. Bahan Pelatihan Penguatan Metodologi Pembelajaran Berdasarkan Nilai-Nilai Budaya untuk Membentuk Daya Saing dan Karakter Bangsa. Jakarta: Kementerian Pendidikan Nasional Badan Penelitian dan Pengembangan Pusat Kurikulum.

Hendro, 2011. Dasar - Dasar Kewirausahaan, Erlangga, Jakarta.

Kasmir. 2006. Kewirausahaan. Jakarta: PT Raja Grafindo Persada.

Khabibah. S. 2006. Pengembangan pembelajaran matematika dengan soal terbuka untuk meningkatkan kreatifitas siswa sekolah dasar. Disertasi yang tidak dipublikasikan oleh pascasarjana UNESA.

Muhafid,E.A. 2015. Peningkatan Scientific Skills Siswa melalui Implementasi Model Problem Based Learning (PPL) pada Pembelajaran IPA Di SMP/MTs Kelas VII. Prosiding Seminar Nasional Pendidikan Sains (SNPS), 375-384 ISSN: 2407-4659. 
Nisa, Siti Choirun.2018 Pelaksanaan Ekstrakurikuler Enterpreneur dalam Mengembangkan Karakter Wirausaha Peserta Didik di MTs Negeri 1 Kota Palembang. Skripsi. Prodi Manajemen Pendidikan Islam UIN Raden Fatah Palembang.

Otuya, R; P. Kibas, J. Otuya, 2013. A Proposed Approach for Teaching Entrepreneurship Education in Kenya, Journal of Education and Practice, Vol.4, No.8, pp.204-210.

Rachmadyanti, Putri dan Vicky Dwi Wicaksono. 2016. Prosiding Seminar Nasional Inovasi Pendidikan: Pendidikan Kewirausahaan Bagi Anak Usia Sekolah Dasar. Surabaya: Universitas Negeri Surabaya.

Saroni, M. 2012. Mendidik dan Melatih Entrepreneur Muda. Yogyakarta : ArRuzz Media.

Shane, S; E. Locke and C.J. Collins. 2003. Entrepreneurial motivation. Human Resource Management Review, 13(2), 257-279

Suherman, E. 2010. Desain Pembelajaran Kewirausahaan. Bandung: Alfa Beta.

Suwithi, Ni Wayan. 2019. Modul Pelatihanpenguatan Kepala Sekolah Pengembangan Kewirausahaan (MPPKS - KWU). Jakarta: Dirjen GTK Kemendikbud.

Wahyuni, Widia Riska \& Hidayati, Wiji. 2017. Peran Sekolah dalam Membentuk Keterampilan Wirausaha Berbasis Tauhid di SD Entrepreneur Muslim Alif-A Piyungan Bantul Yogyakarta. Manageria: Jurnal Manajemen Pendidikan Islam, Volume 2, Nomor 2.

Wardhana, Dony S. 2013. 100\% Anti Nganggur (Cara Cerdas Menjadi Karyawan atau Wirausahawan). Bandung: Ruang Kata.

Wibowo, A. 2011. Pendidikan Kewirausahaan (Konsep danStrategi). Yogyakarta: Pustaka Pelajar.

Wijatno Serian. 2009. Pengantar Entrepreneurship. Jakarta: PT Gramedia Widiasarana Indonesia. 